\title{
EFL Teachers' Perceptions on the Potential of MOOCs for Lifelong Learning
}

\author{
Francisco Javier Palacios-Hidalgo, Universidad de Córdoba, Spain \\ (iD https://orcid.org/0000-0002-4326-209X \\ Cristina A. Huertas-Abril, Universidad de Córdoba, Spain \\ (iD) https://orcid.org/0000-0002-9057-5224 \\ María Elena Gómez-Parra, Universidad de Córdoba, Spain \\ (iD) https://orcid.org/0000-0001-7870-3505
}

\begin{abstract}
Despite its numerous advantages, globalization, information society and the emergence of information and communication technologies (ICT) have caused quick changes in society, provoking the rapid obsolescence of knowledge and the appearance of new concepts. In this context, new professional demands for teachers are required to help students develop necessary competences for the 21 st century. At this juncture, ICT, e-learning tools, and MOOCs have arisen as remarkable training resources for teacher lifelong learning with an undeniable potential; however, it seems relevant to study whether teachers agree in the usefulness of such tools. In this light, this article investigates and compares the perceptions of Spanish pre-service and in-service EFL teachers about ICT, e-learning and MOOCs, and the uses of these technologies. The results obtained allow the researchers to analyze whether the possibilities of these resources correspond to the real necessities of EFL teachers.
\end{abstract}

\section{KEYWORDS}

Continuing Education, Digital Competence, Digital Literacy, E-Learning, Learning Environments, Online Courses, Online Education, Teacher Training

\section{INTRODUCTION}

In recent years, education has dramatically evolved driven by the economic, political and social development of nations all around the world. At this juncture, new technological paradigms have emerged (Sanz, \& Pantoja, 2015). Although these transformations and changes have always been present at schools, their strength has radically increased during the last years due to forces reconfiguring the economic and social reality of the world (Caldevilla, 2011; Casani, \& Rodríguez, 2015). In this context, both developed and developing countries are investing large amounts of money, time and effort in improving their education systems by changing curricula and training programs, improving facilities and supporting educational research, among other actions (Baglieri, Baldi, \& Tucci, 2018; Munari, Sobrero, \& Toschi, 2018).

Technology plays a key role in preparing citizens of the $21^{\text {st }}$ century. In this sense, a new educational research line, Educational Technology, has started with the objective to respond to the needs of this new society and the use of Information and Communication Technologies (ICT). 
According to Hsu, Hung, \& Ching (2013), its definition has evolved over the years, from studies that considered it a variation of ways of dealing with learning processes (Ely, 1963), to the latest ones that define it as means of dealing with technological processes and resources (Januszewski, \& Molenda, 2007), with several attempts to create a conceptual framework (Davies, \& Schwen, 1971) and analyze theory and practice (Seels, \& Richey 1994). Nowadays this field seeks to integrate ICT in the teachinglearning process as a support tool combined with new teaching methodologies, where the teacher acts more as a guide for students than as a mere presenter of contents (Rodríguez, \& Gómez, 2017).

Additionally, language education in general and English as a Foreign Language (EFL) learning/ teaching in particular cannot be understood without the help of technology anymore (Tejada, \& Fernández, 2018). As mentioned by the European Parliament and the Council of Europe (2006) and Instituto Cervantes (2012), digital competence is one of the key competences for second/foreign language teaching and lifelong learning, defined by Parisi, Tani, Weber, \& Wermter (2017) as the human ability to continually acquire, refine and transfer skills as well as knowledge throughout their lifespan, an essential element for cognitive development. In other words, it can be understood as a self-motivated search for knowledge for professional or personal intentions, or even both.

At this point, it is relevant to clarify what a competence is:

A competence is more than just knowledge or skills. It involves the ability to meet complex demands, by drawing on and mobilising psychosocial resources (including skills and attitudes) in a particular context. For example, the ability to communicate effectively is a competence that may draw on an individual's knowledge of language, practical IT skills and attitudes towards those with whom he or she is communicating. (OECD, 2005, p. 4)

Competences have become essential elements at all stages of education, both formal and nonformal (Gutiérrez, \& Serrano, 2016). For instance, current Spanish educational legislation establishes that the curriculum must include "the competences and capacities for the integral application of the contents proper to each teaching and education stage in order to ensure the appropriate performance of activities and the effective resolution of problems" (LOMCE, 2013, p. 10, translated in Gutiérrez, \& Serrano, 2016, p. 51).

These competences can be numerous (Peklaj, 2015). Nevertheless, some of the essential competences that teachers in the $21^{\text {st }}$ century need include (i) subject and teaching skills, (ii) the ability to link theory with practice, (iii) cooperation and collaboration with other colleagues, (iv) self-confidence, (v) leadership, (vi) continuous learning, and (vii) digital knowledge (Hepp, Prats, \& Holgado, 2015, p. 33).

Knowing what a competence is, and considering the aforementioned types, it is necessary to think about which competences teachers require in order to not only become digitally literate (Tafazoli, Gómez, \& Huertas, 2017), but also to be able to integrate ICT into their teaching (Esteve-Mon, Gisbert-Cerbera, \& Lázaro-Cantabrana, 2016, p. 39). In this respect, digital competence and media competence seem to be two of the most relevant. Evidence suggests, however, that teacher education institutions still have some ground to break before they completely include these into their practice. For this reason, this paper aims at reflecting on the concepts of digital and media competences and how they are addressed at universities and teacher-training centers; ultimately, the authors include a series of proposals to facilitate the acquisition and development of digital and media competences by EFL teachers.

\section{BACKGROUND}

Nowadays, ICT play a central role in every field of human life, and the use of technology in every educational stage is developing new, powerful ways that allow a quick access to quality information. 
Not only does this make possible to act directly with present necessities, but also to construct and develop skills for the future. In this context, Massive Open Online Courses, commonly known by their acronym in English MOOCs, have arisen as free, online courses in which students can enroll and collaborate with course-mates from all over the world, deciding how, when and to what extent they are going to participate in it (Moya, 2013, p. 89). Despite having both weaknesses and strengths, MOOCs are a revolution in education due to their great potential and, as Cabero (2015) affirms, they "are becoming one of the technologies of great insight into the educational field in recent times, considered by some as a technology that will create a tsunami on transforming university education" (p. 1).

The relevance that MOOCs are acquiring is due to the fact that they offer a permanent training in constant evolution, which proposes a teaching-learning model based on autonomy and individualization. Moreover, MOOCs have the advantage of free (and/but massive) access to the knowledge. Using these courses entails acting in favor of active, participative and collaborative learning since knowledge is shared with peers. Certainly, the implementation of the tasks and the use of the resources directly depend on participants' implication and their relationship with the rest of the users; however, the intrinsic motivational component of MOOCs seems to produce enough students' participation to create knowledge.

MOOCs also offer great potential for EFL teachers (De la Garza, Sancho-Vinuesa, \& Zermeño, 2015; Palacios, \& Huertas, 2016), and for these reasons, educators have to understand the wide repertoire of learning possibilities and be aware of the potential of these tools in the fields of second language (L2) acquisition, EFL teaching, and the development of communicative and linguistic competences.

Over the last years, literature about MOOCs and their implications in education, especially in e-learning, has increased (Liyanagunawardena, Adams, \& Williams, 2013; López-Meneses, VázquezCano, \& Román-Graván, 2015). The term e-learning encompasses electronically supported teachinglearning which can be delivered by technology both inside and outside the classroom, and whose aim is to enhance a self-paced learning process by using media content in the form of text, images, video and/or audio (Botelho, Agrawal, \& Bornstein, 2019; Donnelly, Benson, \& Kirk, 2012). In other words, it is a virtual learning space whose main aim is to facilitate user's learning experience by intensively using digital tools provided by the Internet.

Participants' opinions about MOOCs are generally positive. There seems to be a prevailing satisfaction towards the usefulness of these courses for learning (Kuo, Walker, Belland, \& Schroder, 2013). A recent study carried out by Li (2019) reveals, however, that learners' level satisfaction varies depending on the type of degrees they have accomplished: in this sense, those who have higher degrees tend to be more satisfied, probably because of the motivation with which they enroll in the courses. In the case of teachers, studies have also revealed their motivation and engagement when taking part in them (Shah, Banerjee, Murthy, \& Iyer, 2018).

Several proposals have assessed the pedagogical quality of MOOCs (Hernández, López, \& Heredero, 2016; Ramírez, 2015; Roig-Vila, Mengual-Andrés, \& Suárez, 2014), as well as the perceptions of students (Bruff, Fisher, McEwen, \& Smith, 2013; Costello, Brunton, Brown, \& Daly, 2018; Xiao, 2019). As for MOOCs' benefits for teachers, few studies have focused on their professional development (Gonçalves, \& Osório, 2018; Koukis, \& Jimoyiannis, 2018), and even fewer have put attention to analyzing language teachers' perceptions on the usefulness of these courses (Koukis, \& Jimoyiannis, 2019); in all these cases, MOOCs have been revealed to create efficient environments to enhance teachers' pedagogical knowledge, active engagement, peer interaction and classroom practices as well as to promote professional development.

However, neither the link between the evaluation of the quality of MOOCs and EFL teachinglearning process nor teachers' perceptions in this field have been addressed in depth yet. 


\section{METHOD}

\section{Objectives of the Study}

The purpose of this study is to compare the perceptions and uses of EFL teachers regarding ICT, e-learning and MOOCs in relation to their lifelong learning/training process, all of it to answer the following research questions: a) Do EFL teachers know about MOOCs and their potential for professional lifelong learning/training process?, b) Have EFL teachers had experience using ICT, e-learning tools and MOOCs for their lifelong learning/training process?, and c) Do EFL teachers believe in the usefulness of ICT, e-learning tools and MOOCs for their lifelong learning/training process? To do so, the authors, after reviewing the literature and gather information about the possibilities that MOOCs and e-learning resources offer in the field of EFL teachers' training, collected data about the perceptions of EFL teachers about the quality of MOOCs and e-learning platforms for their training process. A non-experimental quantitative, descriptive, comparative and co-relational method has been followed through the use of a questionnaire of evaluation (Brown, 2001; McMillan, $\&$ Schumacher, 2001). On the one hand, through this quantitative methodology, the authors have used numerical values to obtain information about the perceptions and uses of EFL teachers about ICT, e-learning platforms and MOOCs; on the other hand, it was not possible to manipulate neither the perceptions nor the uses collected and analyzed, thus the method was non-experimental, as well as descriptive, qualitative, and co-relational, since analysis parameters and relationships among the variables were described; finally, the research design was comparative, since, in short, the authors intended to examine the differences between the information given by the participants (Mateo, 2004).

Ultimately, the authors discuss whether the possibilities of e-learning and MOOCs in teachers' training correspond to the perceptions of EFL teachers.

\section{Participants}

A survey was conducted among pre-service and in-service teachers in Spain in order to analyze the differences in the use of technology between pre-service teachers and in-serve teachers, paying a special attention to e-learning and MOOCs for lifelong learning. The questionnaire was personally administered via convenience sampling from September 2017 to November 2017. A total of 92 surveys was issued, of which 88 were valid.

The sample $(\mathrm{n}=88)$ was almost balanced in terms of gender, with a moderate predominance of women $($ women $=55$; men $=32$; not answered $=1$ ), and it included both pre-service and in-service teachers (pre-service $=65$; in-service $=18$; other $=4$; not answered $=1$ ), with ages ranging from 19 to 49 years old.

Prior to the data collection, four categories were identified: (i) pre-service EFL teachers (31 students of the 4th year of the Degree in Primary Education currently studying the specialization in TEFL at the University of Córdoba, Spain); (ii) pre-service CLIL teachers (24 students of the bilingual group of 3rd year of the Degree in Primary Education of the University of Córdoba); (iii) students of the Master's Degree in Advanced English Studies and Bilingual Education of the University of Córdoba (7 participants; some only studying, others both studying and working as EFL teachers); and (iv) in-service EFL and CLIL teachers.

\section{Instruments, Data Gathering and Analysis}

To gather information from participants, an evaluation questionnaire was designed. This tool contains a total of 17 items classified in three dimensions (ICT; e-learning tools; MOOC), each of them expressed in a four-point Likert scale ( $1=$ totally disagree; $2=$ disagree; $3=$ agree; $4=$ totally agree $)$, to prevent in-between responses when participants are not sure their answers and avoid central tendency bias (Douven, 2018). As participants were not native speakers of English, the questionnaire was designed entirely in Spanish to avoid possible misunderstandings when reading and answering the questions. 
The questionnaire was validated using the Delphi method, a technique to gather information based on consulting experts in an area in order to obtain a reliable agreement of the consulted group. The experts (one EFL university professor, one applied linguistics university lecturer, and one computer engineer specialized in e-learning) were individually asked to revise the instrument under consideration and give feedback in order to help the authors modify and improve its quality (Hsu, \& Sandford, 2007, p. 1; Reguant-Álvarez, \& Torrado-Fonseca, 2016, p. 88). Each item was presented to the expert panel members in the form of a four-point Likert scale to be analyzed according to a double parameter: accuracy and adequacy, and a section for additional comments was also included. Then, the experts of the panel marked their level of agreement with each statement, and suggested all their proposals to improve the formulation of the items by using free text feedback. After the validation round, the authors removed any proposed item that did not meet the requirements and those that were not accurate enough were reformulated to meet the requirements of the experts' panel.

Cronbach's Alpha was also applied to the questionnaire in order to measure its internal consistency and reliability (Quero, 2010) using the SPSS v.24 for MacOS. In this sense, the closer the coefficient is to its maximum value, 1 , the better the reliability is; however, in social sciences, it is considered that alpha values higher than 0.7 are sufficient to assure consistency of the instrument (George, \& Mallery, 2003). The result was .824 for the total of items, thus reliability and consistency of the questionnaire were guaranteed, as it is an exploratory research. All the data obtained were also analyzed using the SPSS v.24 for MacOS. Descriptive statistics were used to report on the results obtained for the different items; the central tendency (mean, median, and mode) and dispersion measures (standard deviation) were also calculated. Moreover, the t-test was employed to determine the existence of statistically significant differences between genres.

\section{RESULTS}

This study had a significant return rate, as the questionnaire was completed by 88 participants a total of 94 who were asked to take part in the study, of whom 32 are men (36.8\%), 55 are women (63.2\%), and 1 subject did not indicate their gender. They were both pre-service $(74.7 \%)$ and in-service teachers (20.7\%), besides 4 others who answered 'other' and one who did not reveal their work situation (4.6\%). They were young and middle-aged students and professionals, with the most representative age group being $19-27$ (86.75\%), followed by $30-35$ (4.82\%) and 37-49 (8.43\%). Figure 1 shows the distribution of participants per age, gender and working situation.

The first dimension of the questionnaire (items 1-6) analyzed the use in general of ICT (see Figure 2). Regarding the convenience of using when participants were asked if the felt comfortable using ICT in their daily lives, $94.3 \%$ of them answered positively, while only $5.7 \%$ of them claimed to feel uncomfortable when dealing with ICT. Most of the participants $(85.2 \%)$ considered they had enough knowledge to use ICT. When reflecting on the reasons to use ICT, two options were considered in the study: leisure and academic/professional purposes. On the one hand, $93.1 \%$ of the sample claimed to use ICT for leisure purposes, while $89.2 \%$ used them in their academic/professional life, and $60.3 \%$ also declared to frequently use social networks in their training process as EFL teachers. In relation to the usefulness of ICT for improving the level of English, almost all of them (96.6\%) agreed with the idea of ICT being helpful for developing proficiency in the language.

The second dimension consisted of the following six items (items 7-12), which referred to the use of e-learning tools (see Figure 3). In the case of the use of the Internet as a tool for EFL teacher training, $96.6 \%$ used the Internet as a learning resource and, in the same way, they claimed having had good experiences using it.

Regarding the use of apps for learning/improving their level of English (for example, Duolingo, Lingua.ly, Babbel or online dictionaries), $79.1 \%$ revealed they had used this kind of software applications and $88.7 \%$ confessed to having had good learning experiences when making use of these resources. Similarly, $80.2 \%$ of the sample agreed with the usefulness of e-learning tools for 
Figure 1. Distribution of participants

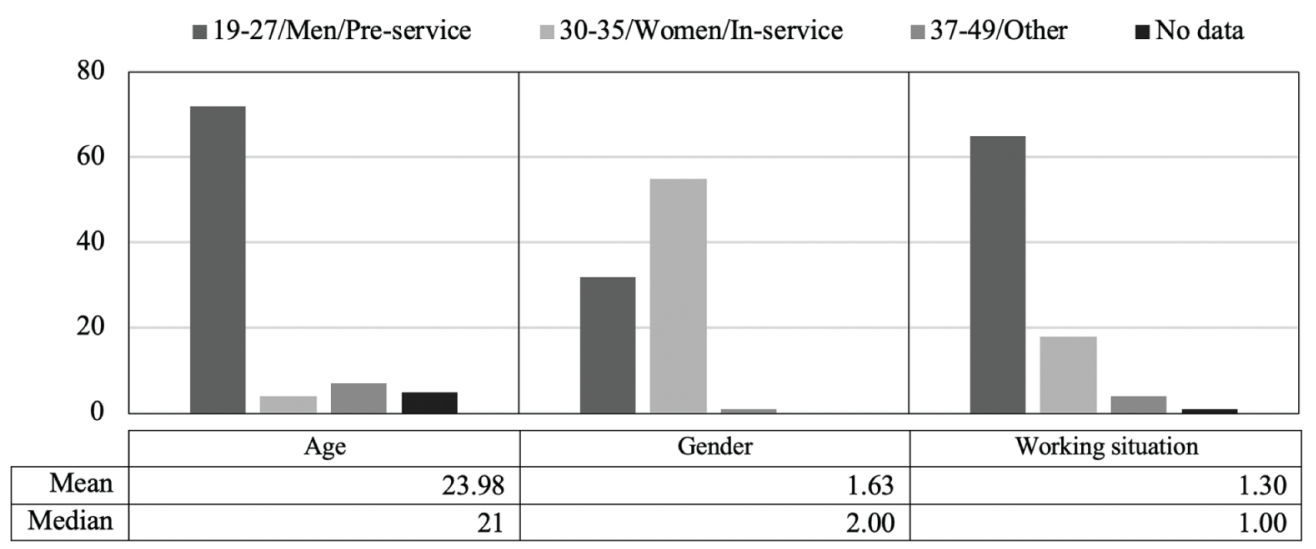

Figure 2. Use of ICT

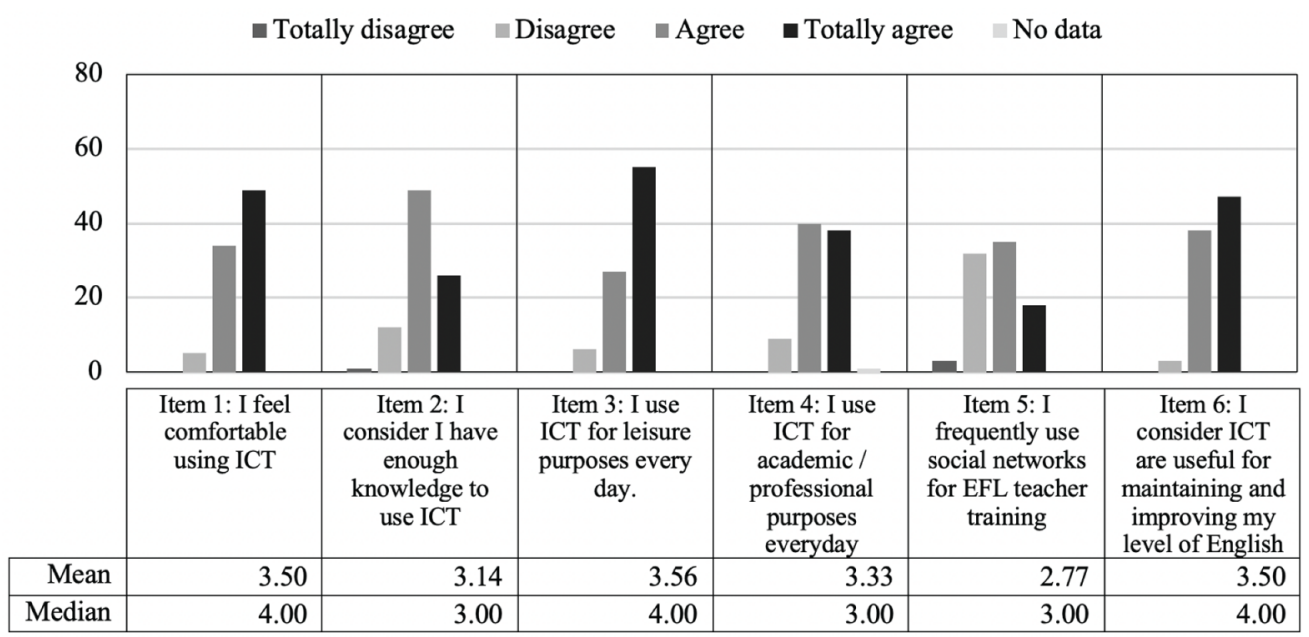

improving the level of English and $94.3 \%$ believed in the with power of e-learning for improving EFL teacher's work.

The final five items were concerned with MOOCs (see Figure 4). Variables 13 and 14 (information about MOOCs and information about MOOC platforms, respectively) were considered key questions in the study, as information to analyzed following items hinged on whether informants knew about MOOCs and their platforms (when the value of these two questions was negative, the following answers were not considered in order to guarantee reliability of the results). These two items revealed that only $64.7 \%$ and $35.3 \%$ of the participants respectively had heard about these courses and the platforms that offer them.

Once items 13 and 14 were analyzed, only 28 responses were considered for the rest of the study. In this sense, out of these 28 teachers, $75 \%$ had had positive learning experiences when using MOOCs, $100 \%$ of them believed in the usefulness of the courses for improving the level of English, and $96.4 \%$ thought they were useful for EFL teacher training.

Finally, t-test allowed to analyze which variables yielded statistically significant differences between groups; for two groups to be significantly different, the value of each after analysis must 
Figure 3. Use of e-learning tools

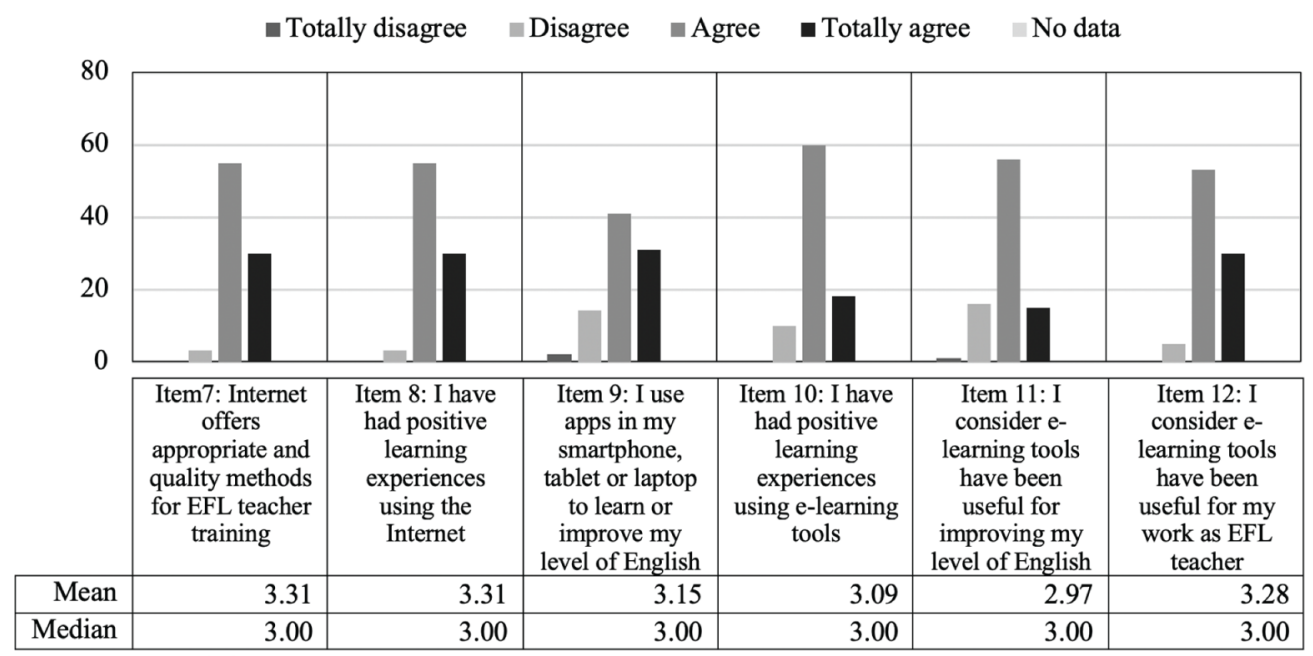

Figure 4. Use of MOOCs

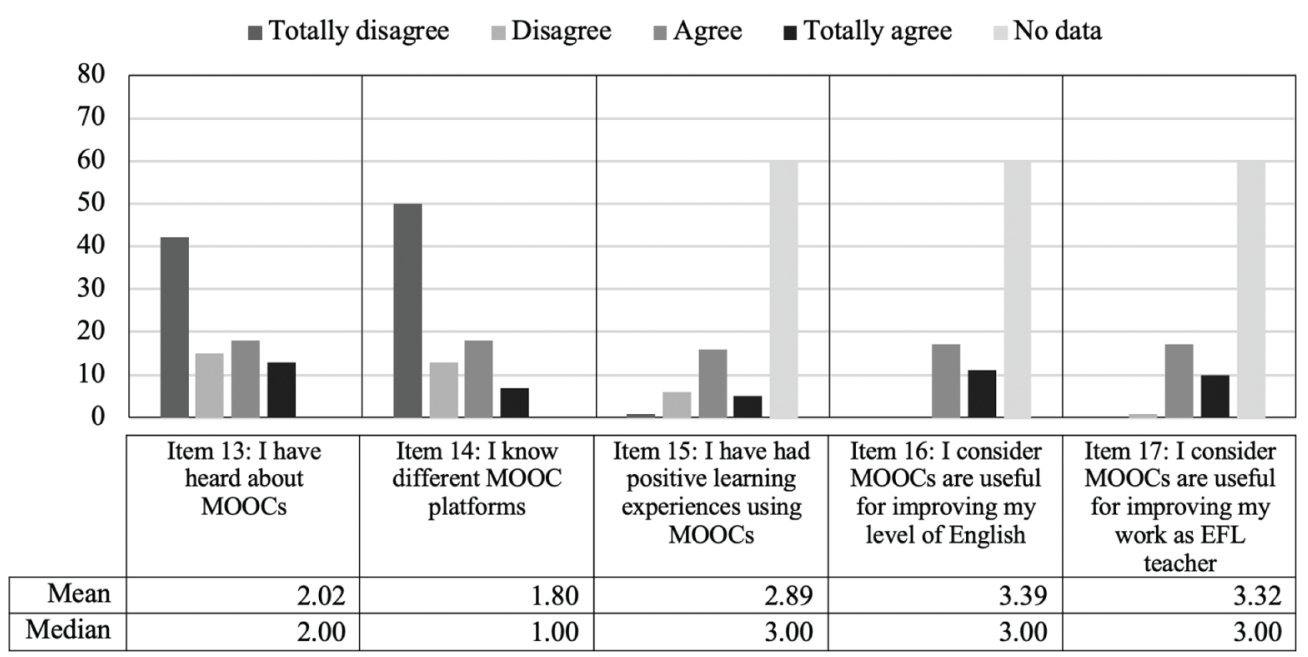

be lower than 0.05 (Fagerland, 2010). According to this, no statistically significant differences were found between pre-service and in-service teachers, neither in pre-graduate and post-graduate students. Nevertheless, it was relevant the t-test between male and female participants in items $1(0.008)$ and $2(0.001)$.

\section{DISCUSSION}

Considering the current socio-educational context, as well as the establishment of English as lingua franca (O'Neil, 2018; Mueller, 2018), there is an increasing demand for active and motivating educational approaches leading to implement effective foreign language methodologies (Moreno, 
Leiva, \& Matas, 2016). In this respect, technologies have an enormous educational potential for teacher trainees.

As already mentioned in the background section, some studies have analyzed students' perceptions towards the use of MOOCs (Bruff, Fisher, McEwen, \& Smith, 2013; Costello, Brunton, Brown, \& Daly, 2018; Kuo, Walker, Belland, \& Schroder, 2013; Li, 2019; Xiao, 2019), showing high levels of motivation and satisfaction when taking part in these courses. Similarly, although to a lesser extent, research has revealed MOOCs' benefits in teachers' motivation, engagement and professional development (Gonçalves, \& Osório, 2018; Hernández, López, \& Heredero, 2016; Koukis, \& Jimoyiannis, 2018; Shah, Banerjee, Murthy, \& Iyer, 2018). Very few studies, like the one carried out by Koukis and Jimoyiannis (2019) focusing on Greek-language teachers, have concentrated on language teachers' perceptions of the use of these courses; despite the scarce research, it has been proved that MOOCs are seen as effective tools for lifelong learning. However, EFL teachers' perceptions have not been addressed in depth yet.

Taking the objectives of the study as a base, this investigation enabled the authors to accomplish an accurate diagnosis of pre-service and in-service EFL teachers' perceptions of ICT, e-learning tools and MOOCs, as well as their main purposes when making use of these resources.

In relation to the use of ICT, the majority of participants claimed they felt comfortable using ICT and they had enough knowledge to use them, but also that they believed they needed better training to employ these technologies. The reason why a great number of them felt convenient about this idea could be due to the fact that most of them were digital natives and not digital immigrants - i.e., they have been using technological and online resources for an ample lapse of time (in fact, the age of the vast majority of the sample was 19-24, which, by definition, implies they should be digital native). Similarly, informants considered they had enough knowledge to use them in many diverse situations; however, the number was reduced, possibly because they did not believe having received proper training in this field or because what they had learnt was not enough for being/becoming digitally competent.

Moreover, significant information was revealed on the different uses EFL teachers make of information technologies in their daily lives. It is obvious that in our current information/network society ICT are mainly used for leisure purposes and, in fact, respondents corroborated the idea (93.2\% of participants acknowledged using these technologies everyday as a way for entertainment); additionally, mostly all informants employed these tools for professional and/or academic intentions (Table 1). The explanation for this is understandable if the role that electronic communications play in society and education are considered, together with the social implications of globalization (Martínez, 2019). All this makes people feel the necessity to interact and create all types of relationships and far-flung networks, not only to solve their learning needs but also to develop their social nature.

It must be taken into account that acquiring teaching skills is not the sole imperative requirement for EFL teachers, but it must go hand in hand with proficiency in the language (Bueno, 2006). For this reason, the authors decided to take into account how Internet and ICT help pre-service and inservice teachers learn and maintain their level of English. Among all the possibilities, the authors considered social networks due to their evident social power and their benefits in the creation of relationships (Lin, Warschauer, \& Blake, 2016; Stornaiuolo, DiZio, \& Helming, 2013); however, it seems not all our subjects of study believed in the opportunities these websites offer for improving their knowledge (only $60.3 \%$ claimed using them to enhance their abilities as teachers). Bearing in mind that collaboration is key to a good teaching practice (Van Houten, 2015), universities should consider including social networks in their curricula and syllabuses so that pre-service EFL teachers (and teachers in general) could have a clear idea of their potential for building and sharing knowledge.

In connection with the need for improving both teaching and language skills, and despite the fact that only some participants confessed they used social networks with professional purposes, ICT are seen as useful and effective means for learning English and becoming a properly full-prepared EFL teachers. It is undeniable the potential of new technologies in every field of human life, but especially in education, where e-learning is becoming more and more widespread in terms of formative 
Table 1. Use of ICT for leisure purposes vs. Academic/professional purposes

\begin{tabular}{|l|l|l|l|l|}
\hline \multirow{2}{*}{} & \multicolumn{2}{|c|}{ Leisure } & \multicolumn{2}{c|}{ Academic/Professional } \\
\cline { 2 - 6 } & \multicolumn{1}{|c|}{ F } & \multicolumn{1}{c|}{ F } & \multicolumn{1}{c|}{$\%$} \\
\hline Totally Disagree & 0 & - & 0 & - \\
\hline Disagree & 6 & $6.8 \%$ & 9 & $10.3 \%$ \\
\hline Agree & 27 & $30.7 \%$ & 40 & $46 \%$ \\
\hline Totally Agree & 55 & $62.5 \%$ & 38 & $43.7 \%$ \\
\hline
\end{tabular}

strategies (Gómez-Puerta, Lorenzo, Arráez, \& Lorenzo, 2018; Serrano-Pastor, \& Casanova-López, 2018). In this sense, pre-service and in-service teachers may have a clear idea of and appreciate what ICT offer, as they believe e-learning provides them with a more individualized training adapted to their own learning rhythm.

In general terms, surveyed EFL teachers were aware of their need for updating themselves faster and constantly in such changing context as they must help students of the $21^{\text {st }}$ century acquire the skills society demands (Sanz, \& Pantoja, 2015); in this regard, they considered this formative modality could really help them enhance their work as professionals of education, as they claimed having had good learning experiences when following an online learning plan.

Concerning e-learning tools, apps can be considered as probably the most handful online learning modality due to their flexibility and facility of use; in fact, many of them can be easily found when it comes to practicing and learning English (e.g. Duolingo, Lingua.ly and Babbel, as well as online dictionaries). In this respect, a considerable part of the sample revealed they had a positive opinion on the use of these apps for learning and improving and practicing their English. On another note, data on learning background when utilizing the Internet and e-learning resources were quite similar (Table 2) as almost all participants declared they had had good experiences using the Internet and e-learning tools.

It could be argued that e-learning is not as useful as traditional learning in terms of procrastination and abandonment (Badia, Dezcallar, \& Cladellas, 2018); nevertheless, it cannot be obviated its educational potential (as it provides time flexibility and individualized study, since students choose when and where training will take place) and its democratizing power (as it helps overcome geographical barriers for those who cannot access to on-site education) (De la Garza, Sancho-Vinuesa, \& Zermeño, 2015; Palacios, \& Huertas, 2016), and surveyed EFL teachers were mindful of it.

As for the use of MOOCs, it is surprising that not many participants knew about neither these open courses nor the online platforms that offer them (Table 3) before the study, a sign of the few information given about them in universities or maybe the lack of interest of pre-service teachers and recent graduates in new and cutting-edge training possibilities. This leads us to the necessity of providing new professionals of education with plenty of information about MOOCs, as it has

Table 2. Positive learning experiences using internet and e-learning tools

\begin{tabular}{|l|l|l|l|l|}
\hline \multirow{2}{*}{} & \multicolumn{2}{|c|}{ Internet } & \multicolumn{2}{c|}{ E-Learning Tools } \\
\cline { 2 - 5 } & \multicolumn{1}{|c|}{ F } & \multicolumn{1}{c|}{ F } & \multicolumn{1}{c|}{$\%$} \\
\hline Totally Disagree & 0 & - & 0 & - \\
\hline Disagree & 3 & $3.4 \%$ & 10 & $11.4 \%$ \\
\hline Agree & 55 & $62.5 \%$ & 60 & $68.2 \%$ \\
\hline Totally Agree & 30 & $34.1 \%$ & 18 & $20.5 \%$ \\
\hline
\end{tabular}


already been demonstrated that they propose a teaching-learning model based on autonomy and individualization and free and massive access to the knowledge.

Moreover, informants who knew about these courses showed they had had good learning experiences; nevertheless, it is remarkable the considerable high percentage of participants who claimed not having experienced a good learning process when taking part in MOOCs. This may have been caused by poorly designed courses or users' difficulties for autonomous and self-directed learning.

The motivational component of these online courses is another unquestionably important element. In this sense, there seems to be correspondence between EFL teachers' perceptions about the utility of MOOCs for improving the level of English and strengthening teaching skills. The $100 \%$ of subjects considered in this section believed these courses are relevantly useful for acquiring proficiency in English, while almost all of them thought they help promote good teaching practices (Table 4). These results correlate with previous studies which revealed the usefulness of courses and participants' satisfaction toward them (Kuo, Walker, Belland, \& Schroder, 2013; Li, 2019; Shah, Banerjee, Murthy, \& Iyer, 2018). It is evident the lack of predisposition towards English language learning, probably because of the use of grammar-teaching-centered and teacher-centered approaches which do not promote the active use of the language and have been used for many years as the main TEFL method (Ahmed, 2013); luckily, surveyed EFL teachers relied on the usefulness of MOOCs

Table 3. Information about MOOCs and MOOC platforms

\begin{tabular}{|c|c|c|c|c|}
\hline & \multicolumn{2}{|c|}{ MOOCs } & \multicolumn{2}{|c|}{ MOOC Platforms } \\
\hline & $\mathbf{F}$ & $\%$ & $\mathbf{F}$ & $\%$ \\
\hline Totally Disagree & 42 & $47.7 \%$ & 50 & $56.8 \%$ \\
\hline Disagree & 15 & $17 \%$ & 13 & $14.8 \%$ \\
\hline Agree & 18 & $20.5 \%$ & 18 & $20.5 \%$ \\
\hline Totally Agree & 13 & $14.8 \%$ & 7 & $8 \%$ \\
\hline
\end{tabular}

not only in proficiency's acquisition but also teaching skills' development.

Noteworthy differences between men and women were not found, with the only exception of two variables: knowledge to use ICT and experiences using MOOCs, as also shown with the $t$-test. In relation to the former, men considered they have more knowledge to use ICT (96.9\%, against the $21.8 \%$ who thought they needed extensive training for using these technologies) than women (only the $78.2 \%$ answered they believed they had necessary skills to employ them). As for the latter, again more men than women declared having had positive learning experiences participating in MOOCs

Table 4. MOOCs usefulness to improve the level of english and EFL teaching skills

\begin{tabular}{|l|l|l|l|l|}
\hline \multirow{2}{*}{} & \multicolumn{2}{|c|}{ Level of English } & \multicolumn{2}{c|}{ EFL Teaching Skills } \\
\cline { 2 - 6 } & \multicolumn{1}{|c|}{ F } & \multicolumn{1}{c|}{$\%$} & \multicolumn{1}{c|}{ F } & \multicolumn{1}{c|}{} \\
\hline Totally Disagree & 0 & - & 0 & - \\
\hline Disagree & 0 & - & 1 & $3.6 \%$ \\
\hline Agree & 17 & $60.7 \%$ & 17 & $60.7 \%$ \\
\hline Totally Agree & 11 & $39.3 \%$ & 10 & $35.7 \%$ \\
\hline
\end{tabular}


(90.9\% of male subjects against $64.7 \%$ of females). The following table (Table 5) illustrates gender distinctness.

Table 5. Gender differences in knowledge to use ICT and experiences using MOOCs

\begin{tabular}{|l|l|l|l|l|}
\hline \multirow{2}{*}{} & \multicolumn{2}{|c|}{ Knowledge of ICT } & \multicolumn{2}{c|}{ Experiences Using MOOCs } \\
\cline { 2 - 5 } & \multicolumn{1}{|c|}{ F } & \multicolumn{1}{c|}{ F } & \multicolumn{1}{c|}{$\%$} \\
\hline Totally Disagree & - & $1.8 \%$ & - & $5.9 \%$ \\
\hline Disagree & $3.1 \%$ & $20 \%$ & $9.1 \%$ & $29.4 \%$ \\
\hline Agree & $50 \%$ & $58.2 \%$ & $63.6 \%$ & $52.9 \%$ \\
\hline Totally Agree & $46.9 \%$ & $20 \%$ & $27.3 \%$ & $11.8 \%$ \\
\hline
\end{tabular}

In general, EFL teachers considered ICT as useful tools for improving both their level of English and their teaching skills; as for e-learning, this innovative educational method was considered by pre-service and in-service teachers to provide them with an individualized, motivating and effective training adapted to their own learning rhythm.

When it comes to knowledge and perceptions of MOOCs, however, results were quite different. It was found that few surveyed EFL teachers actually knew about these courses and, thereby, about their potential. It can be concluded in this respect that universities and teacher-training centers should provide pre-service and in-service teachers with plenty information about theses and encourage them to look for new training possibilities in order to develop and upgrade their teaching skills.

Definitely, as several studies have revealed (Matías, \& Pérez, 2014; Perifanou, \& Economides, 2014), the motivational component of MOOCs and e-learning tools is unquestionable and necessary considering the globalized world where we live nowadays. Notwithstanding, EFL teachers need to be inspired to use these resources and take advantage of what they offer, specially MOOCs, as they help promote an active use of the language, motivation towards learning and, in general, strong educational power.

\section{CONCLUSION}

It is undoubtable the changing tendency of the current social, economic and educational context due to technological advances and the establishment of English as lingua franca. In this setting, new knowledge is being created and, as a consequence, modern training methods are required for teachers to help students develop necessary competences for the $21^{\text {st }}$ century.

In the last decades, ICT and e-learning have acquired a remarkable relevance, and they have been started to be included in curricula and syllabuses of universities from all over the world. Similarly, MOOCs are receiving more and more importance; their innovative nature is undeniable and their potential as formative tools for language learning is enormous due to the type of didactic methodology these courses set out: autonomous and equal learning, quality contents, flexibility, and adaptation to user's characteristics and needs.

Much has been written on the power and possibilities of e-learning and MOOC for teacher training and learning in general; it has been proven that e-learning and MOOCs have a become a reality in every field of education (even in EFL learning and teaching) and that, in fact, educational institutions now develop a great component of their offer though online platforms. Nevertheless, as these technological resources are becoming the core of online education, it seemed relevant to reflect on such high expectations coming from the use of new technologies and compare whether teachers 
agree on their effectiveness for learning. For this reason, this paper tried to compare the perceptions and uses of EFL teachers regarding ICT, e-learning and MOOCs in relation to professional lifelong learning/training process.

Findings reveal that, in general, EFL teachers consider ICT are useful for improving both their level of English and their teaching skills; as for e-learning, this innovative educational method is considered by pre-service and in-service teachers to provide them with an individualized, motivating and effective training adapted to their own learning rhythm.

When it comes to knowledge and perceptions of MOOCs, however, results are quite different. It has been found that few surveyed EFL teachers actually know about these courses and, thereby, about their potential. It can be concluded in this respect that universities and teacher-training centres should provide pre-service and in-service teachers with plenty information about theses, as well as the varied range of ICT available for them to use throughout their learning processes, and encourage them to look for new training possibilities in order to develop and upgrade their teaching skills. In this sense, digital and media competences should be included in syllabuses; these could be defined as a set of attitudes, knowledge and skills that allow us to face today's digital/media environment by using ICT for work, leisure and communication in order to adapt to constant changes and different contexts (Hepp, Prats, \& Holgado, 2015; Ramírez, Renés, \& González, 2018). Such competences should be considered as essential elements of pre-service teachers' education in order to guarantee they have the necessary skills and knowledge to face the challenges posed by $21^{\text {st }}$ century society and use ICT and MOOCs properly. To do so, universities should create a digital environment in the classroom that help developing the aforementioned competences and, ultimately, fostering professional development.

The motivational component of MOOCs and e-learning tools is unquestionable and also necessary considering the globalized world where we live nowadays. Notwithstanding, EFL teachers need to be inspired to use these resources and take advantage of what they offer, specially MOOCs, as they help promote an active use of the language, motivation towards learning and, in general, strong educational power.

It seems relevant to review/revisit the research questions of this study. As for the first one (Do EFL teachers know about MOOCs and their potential for professional lifelong learning/training process?), the study has revealed that few participants actually knew about MOOCs and their didactic implications; as for the second (Have EFL teachers had experience using ICT, e-learning tools and MOOCs for their lifelong learning/training process?) and third ones (Do EFL teachers believe in the usefulness of ICT, e-learning tools and MOOCs for their lifelong learning/training process?), those who knew about the existence of MOOCs claimed to have had positive contact with these courses.

In this sense, we offer some recommendations for universities and training centers to provide teachers with information about MOOCs and their potential for professional lifelong learning process, as well as to include the development of digital and media competences as key objectives in their syllabi and curricula.

Although the study is limited, it should be only the first phase of a deeper research into online courses' utility and efficacy as a formative instrument for every level and area of education, as it can be extended to any other language, area of knowledge and/or educational stage. It would be attractive in this sense to carry out a research project on the perceptions that teachers of other foreign languages (such as French, German or Italian) have towards the use of e-learning and online courses, as well as the use of these in Early Childhood, Primary, Secondary or Higher Education. In this light, it is important to highlight some of the limitations of the study, which may have been previously inferred; in particular, the small size of the sample and the fact that there was a remarkable number of data losses due to the two key variables in order to not to have distorted results. As previously indicated, few surveyed informants confess knowing about MOOCs and their didactic power; accordingly, a report on the possibilities of these courses could be designed and spread among pre-service and inservice teacher to make sure they are provided with information about how they could improve their proficiency in English and their teaching abilities. 
Even though the possibility of continuing this study is truly ambitious, it also seems acceptable, feasible, and achievable, besides its potential could be pivotal for the new challenges that education is facing these days. 


\section{REFERENCES}

Ahmed, A. K. (2013). Teacher-centered versus learner-centered teaching style. The Journal of Global Business Management, 9(1), 22-34.

Badia, M. del M., Dezcallar, T., \& Cladellas, R. (2018). Uso lúdico de las TIC, procrastinación y género: un estudio con alumnos de educación primaria. Aloma: Revista de Psicologia. Ciències de l'Educació i de l'Esport, $36(2), 33-40$.

Botelho, M. G., Agrawal, K. R., \& Bornstein, M. M. (2019). A systematic review of e-learning outcomes in undergraduate dental radiology curricula-levels of learning and implications for researchers and curriculum planners. Dento Maxillo Facial Radiology, 48(1), 1-10. doi:10.1259/dmfr.20180027 PMID:30028185

Brown, J. D. (2001). Using Surveys in Language Programs. Cambridge: Cambridge University Press.

Bruff, D. O., Fisher, D. H., McEwen, K. E., \& Smith, B. E. (2013). Wrapping a MOOC: Student Perceptions of an Experiment in Blended Learning. MERLOT Journal of Online Learning and Teaching, 9(2), 187-199.

Bueno, A. (2006). La formación del profesorado de inglés como lengua extranjera. Reflexión y competencia profesional. In J. L. de Miguel \& A. Jiménez (Eds.), Maestro y sabio = Didáskalos kaì sophós: homenaje al profesor Juan Jiménez Fernández (pp. 353-378). Jaén: Universidad de Jaén.

Cabero, J. (2015). Visiones educativas sobre los MOOC. Revista Iberoamericana de Educación a Distancia, $18(2), 39-60$.

Casani, F., \& Rodríguez, J. (2015). Cambios y tendencias en la Educación Superior: los retos para la universidad. Encuentros multidisciplinares, 17(49), 30-39.

Costello, E., Brunton, J., Brown, M., \& Daly, L. (2018). In MOOCs we Trust: Learner Perceptions of MOOC Quality via Trust and Credibility. International Journal of Emerging Technologies in Learning, 13(6), $214-222$. doi:10.3991/ijet.v13i06.8447

Davies, I., \& Schwen, T. (1971). Toward a definition of instructional development. Washington: AECT.

De la Garza, L. Y. A., Sancho-Vinuesa, T., \& Zermeño, M. G. G. (2015). Indicators of pedagogical quality for the design of a Massive Open Online Course for teacher training. Revista de Universidad y Sociedad del Conocimiento, 12(1), 104-118. doi:10.7238/rusc.v12i1.2260

Donnelly, P., Benson, J., \& Kirk, P. (2012). How to succeed at e-learning. New Jersey: Wiley-Blackwell. doi:10.1002/9781118308455

Douven, I. (2018). A Bayesian perspective on Likert scales and central tendency. Psychonomic Bulletin \& Review, 25(3), 1203-1211. doi:10.3758/s13423-017-1344-2 PMID:28752379

Ely, D. P. (1963). The changing role of the audiovisual process: A definition and glossary of related terms. Audiovisual Communication Review, 11(1 Supplement 6), 1-6.

Fagerland, M. W. (2010). t-tests, non-parametric tests, and large studies-a paradox of statistical practice? BMC Medical Research Methodology, 12(1), 78-85. doi:10.1186/1471-2288-12-78 PMID:22697476

Gómez-Puerta, M., Lorenzo, G., Arráez, D., \& Lorenzo, A. (2018). B-learning y e-learning como estrategias para el desarrollo de competencias complementarias del alumnado del grado de maestro. International Journal of Developmental and Educational Psychology, 1(1), 163-168.

Gonçalves, B. M. F., \& Osório, A. J. (2018). Massive Open Online Courses (MOOC) to Improve Teachers' Professional Development. RE@D - Revista de Educação a Distância e Elearning, 1(1), 52-63.

Hepp, P., Prats, M. A., \& Holgado, J. (2015). Teacher training: Technology helping to develop an innovative and reflective professional profile. RUSC. Universities and Knowledge Society Journal, 12(2), 30-43. doi:10.7238/ rusc.v12i 2.2458

Hernández, P., López, C., \& Heredero, E. (2016). Calidad de un MOOC sobre inclusión educativa: Aplicación de varios instrumentos e indicadores. Revista Ibero-Americana de Estudos em Educação, 11(25), 342-349. 
Hsu, C., \& Sandford, B. A. (2007). The Delphi Technique: Making Sense of Consensus. Practical Assessment, Research \& Evaluation, 12(10), 1-8.

Hsu, Y. C., Hung, J. L., \& Ching, Y. H. (2013). Trends of educational technology research: More than a decade of international research in six SSCI-indexed refereed journals. Educational Technology Research and Development, 61(4), 685-705. doi:10.1007/s11423-013-9290-9

Januszewski, A., \& Molenda, M. (2007). Definition. In A. Januszewski \& M. Molenda (Eds.), Educational technology: A definition with commentary (pp. 1-14). London: Routledge.

Johnson, L., Adams, S., Cummins, M., \& Estrada, V. (2012). Technology outlook for STEM+Education 20122017: An NMC Horizon Report Sector Analysis. Austin, TX: The New Media Consortium.

Koukis, N., \& Jimoyiannis, A. (2018). MOOCs and Teacher Professional Development: A Case Study on Teachers' Views and Perceptions. In M. Baptista \& P. Isaías (Eds.), MCCSIS 2018 Multi Conference on Computer Science and Information Systems. Proceedings of the International Conference E-Learning 2018 (pp. 19-26). Madrid: IADIS Press.

Koukis, N., \& Jimoyiannis, A. (2019). MOOCs for Teacher Professional Development: Exploring Teachers' Perceptions and Achievements. Interactive Technology and Smart Education, 16(1), 74-91. doi:10.1108/ITSE10-2018-0081

Kuo, Y.-C., Walker, A. E., Belland, B. R., \& Schroder, K. E. E. (2013). A predictive study of student satisfaction in online education programs. International Review of Research in Open and Distance Learning, 14(1), 16-39. doi:10.19173/irrodl.v14i1.1338

Li, K. (2019). MOOC learners' demographics, self-regulated learning strategy, perceived learning and satisfaction: A structural equation modeling approach. Computers \& Education, 132, 16-30. doi:10.1016/j. compedu.2019.01.003

Lin, C.-H., Warschauer, M., \& Blake, R. (2016). Language learning through social networks: Perceptions and reality. Language Learning \& Technology, 20(1), 124-147.

Liyanagunawardena, T., Adams, A., \& Williams, S. (2013). MOOCs: A systematic study of the published literature 2008-12. International Review of Research in Open and Distance Learning, 14(3), 202-227. doi:10.19173/ irrodl.v14i3.1455

López-Meneses, E., Vázquez-Cano, E., \& Román-Graván, P. (2015). Analysis and implications of the impact of MOOC movement in the scientific community: JCR and Scopus (2010-13). Comunicar: Revista Científica de Comunicación y Educación, 22(44), 73-80. doi:10.3916/C44-2015-08

Martínez, M. D. (2019). Usos de las TIC y actitudes de los profesores de lenguas en el contexto de las Escuelas Europeas. Virtualidad. Educación y Ciencia, 18(18), 9-36.

Mateo, J. (2004). La investigación ex post-facto. In R. Bisquerra (Coord.), Metodología de la investigación educativa (pp. 196-230). Madrid: La Muralla.

Matías, H., \& Pérez, A. (2014). Los Cursos en Línea Masivos y Abiertos (MOOC) como alternativa para la educación a distancia. GECONTEC: Revista Internacional de Gestión del Conocimiento y la Tecnología, 2(2), $41-49$.

McMillan, J., \& Schumacher, S. (2001). Research in education: A conceptual introduction. New York: Longman.

Moreno, N. M., Leiva, J. J., \& Matas, A. (2016). Mobile learning, gamificación y realidad aumentada para la enseñanza-aprendizaje de idiomas. IJERI: International Journal of Educational Research and Innovation, (6), 16-34.

Moya, M. (2013). Los MOOC/COMA: Un nuevo reto educativo para el siglo XXI. Una metodología didáctica para el aprendizaje en línea. Virtualis, 4(8), 84-103.

Mueller, J. T. (2018). English as a lingua franca at the multilingual university: A comparison of monolingually and multilingually raised students and instructors. In A. Bonnet \& P. Siemund (Eds.), Foreign Language Education in Multilingual Classrooms (pp. 359-380). Hamburg: John Benjamins Publishing Company. doi:10.1075/ hsld.7.16mue 
O'Neil, D. (2018). English as the lingua franca of international publishing. World Englishes, 37(2), 146-165. doi:10.1111/weng.12293

Palacios, F. J. (2018). Los MOOC como instrumentos para la formación en lengua inglesa del alumnado de sexto curso de Educación Primaria. In M. I. Amor, M. Osuna, \& E. Pérez (Eds.), Fundamentos de enseñanza y aprendizaje para una educación universal, intercultural y bilingüe (pp. 155-160). Barcelona: Octaedro.

Palacios, F. J., \& Huertas, C. A. (2016). MOOCs y formación del profesorado de segundas lenguas: Propuesta de evaluación. Skopos, 7, 151-157.

Papert, S. (1996). The Connected family. Bridging the digital generation gap. Atlanta: Longstreet Press.

Parisi, G. I., Tani, J., Weber, C., \& Wermter, S. (2017). Lifelong learning of humans actions with deep neural network self-organization. Neural Networks, 96, 137-149. doi:10.1016/j.neunet.2017.09.001 PMID:29017140

Perifanou, M. A., \& Economides, A. A. (2014). MOOCs for foreign language learning: an effort to explore and evaluate the first practices. In L. Gómez, A. López, \& I. Candel (Eds.), Proceedings of INTED2014 Conference (pp. 3561-3570). Valencia, Spain: IATED Academy.

Quero, M. (2010). Confiabilidad y coeficiente Alpha de Cronbach. Telos. Revista de Estudios Interdisciplinarios en Ciencias Sociales, 12(2), 248-252.

Ramírez, A., Renés, P., \& González, N. (2018). La competencia mediática a través de los contenidos curriculares en la etapa de educación primaria en España. In C. Fuente, M. C. García, \& C. R. Camilli (Coords.), La educación mediática en España (pp. 399-416). Madrid: Universitas.

Ramírez, M. (2015). Propuesta de certificación de calidad de la oferta española educativa de cursos MOOC realizada por el Instituto Nacional de Tecnologías Educativas y de Formación del Profesorado. International Journal of Educational Research and Innovation, 3, 121-133.

Reguant-Álvarez, M., \& Torrado-Fonseca, M. (2016). El método Delphi. REIRE: Revista d'innovació i recerca en educació, 9(1), 87-102.

Roig-Vila, R., Mengual-Andrés, S., \& Suárez, C. (2014). Evaluación de la calidad pedagógica de los MOOC. Profesorado. Revista de currículum y formación del profesorado, 18(1), 27-41.

Sagar, C. (2016). TICs y aprendizaje de idiomas: ¿existe algún sistema existe de aprendizaje digital y conectado? In R. Roig-Vila (Ed.), Tecnología, innovación e investigación en los procesos de enseñanza-aprendizaje (pp. 1840-1847). Barcelona: Octaedro.

Sanz, M., \& Pantoja, A. (2015). Formación permanente del profesorado en las comunidades de práctica. Aula de encuentro: Revista de investigación y comunicación de experiencias educativas, 1(17), 105-130.

Seels, B., \& Richey, R. (1994). Instructional technology: The definition and domains of the field. Washington, DC: Association for Educational Communications and Technology.

Selwyn, N. (2004). Literature Review in Citizenship, Technology and Learning. Bristol: Futurelab.

Serrano-Pastor, R. M., \& Casanova-López, O. (2018). Recursos tecnológicos y educativos destinados al enfoque pedagógico Flipped Learning. REDU: Revista de Docencia Universitaria, 16(1), 155-173. doi:10.4995/ redu.2018.8921

Shah, V., Banerjee, G., Murthy, S., \& Iyer, S. (2018). Learner-centric MOOC for teachers on effective ICT Integration: perceptions and experiences. In V. Kumar, S. Murthy, \& S. Iyer (Eds.), 2018 IEEE Tenth International Conference on Technology for Education (T4E) (pp. 77-84). IEEE Computer Society. doi:10.1109/ T4E.2018.00023

Stornaiuolo, A., DiZio, J. K., \& Helming, E. A. (2013). Expanding Community: Youth, social networking and schools. Comunicar, 40(40), 79-87. doi:10.3916/C40-2013-02-08

Tafazoli, D., Gómez, M. E., \& Huertas, C. A. (2017). Computer literacy: Sine qua non for digital age of language learning \& teaching. Theory and Practice in Language Studies, 7(9), 716-722. doi:10.17507/tpls.0709.02

Van Houten, J. (2015). Transforming teacher preparation through collaboration. Foreign Language Annals, 48(3), 323-325. doi:10.1111/flan.12154 
Xiao, Z. (2019). Study on Senior High Students' Perceptions of English Grammar Learning and Pedagogic Implications. Within the Domain of English Key Competences. Advances in Social Science. Education and Humanities Research, 311, 297-302.

Francisco J. Palacios Hidalgo is a PhD student at the University of Córdoba and member of the Research Group the Research Group 'Research in Bilingual and Intercultural Education' (HUM-1006). He has experience in TESL TEFL in Primary and Secondary Education and is specialized in English official tests. He develops his Thesis on the results of Spanish bilingual programs. His research focuses on second language teaching and learning, bilingual education and educational technologies.

Cristina A. Huertas (PhD) Abril is an Associate Professor in the Dpt. of English and German Studies of the University of Córdoba, Spain. She is an interdisciplinary researcher working mainly within Bilingual Education, CALL, Educational Technology, and Second/Foreign Language Acquisition. She has participated in several national and international research projects and teaching innovation projects. Dr Huertas-Abril teaches at Master's level at UCO, UCA and UIMP, among which the Erasmus Mundus Joint Master's Degree 'Play, Education, Toys and Languages' (PETaL) can be highlighted. Moreover, she has taught several specialization courses on Bilingual Education and Second Language Acquisition. She is a member of the Research Group HUM-1006 Research in Bilingual and Intercultural Education (EBEI).

María Elena Gómez-Parra, Ph.D. graduated from the University of Granada as an English Philologist and then from the University of Córdoba as a PhD. She holds a Master in Distant Education. Currently, she is an interdisciplinary researcher working mainly within Intercultural Education, Bilingual Education, and English as a Foreign Language. Dr. Gómez-Parra is the director of the Research Group HUM-1006 (Research in Bilingual and Intercultural Education); she is a full member of ATINER, the President of IBIE (Ibero-American Bilingual and Intercultural Education) Network since its foundation, the Director of the Erasmus Mundus Joint Master Degree (EMJMD) entitled Play, Education, Toys and Languages (PETaL), the IP of the Research Project LinguApp: LinguApp: asegurando el acceso al aprendizaje universal e inclusivo de segundas lenguas' (Ref. no. PRY208/17, funded by Centro de Estudios Andaluces, July 2017-July 2019), the IP of the Research Spanish National Project entitled 'Facing Bilinguals: Study of Bilingual Education Programmes' Results through Social Data Analysis' (2018-2021), the Director of the prestigious UIMP (Universidad Internacional Menéndez Pelayo) training courses for Spanish Primary Education Teachers entitled: 'Innovation within CLIL: Mindfulness, Design Thinking and ICT' (Cuenca, 10th-14th July 2017), as well as for Secondary Bilingual Teachers: 'Innovation in Bilingual Secondary Education' (Cuenca, 9th-13th July 2018). She is also a reviewer for a number of international journals on education, second languages and culture. 